\title{
ЖУРНАЛІСТСЬКІ СТАНДАРТИ В УМОВАХ ВІЙНИ: ПОЗИЦІЯ ГРОМАДЯНИНА ЧИ ОБ'ЄКТИВНИЙ ПРОФЕСІОНАЛІЗМ
}

\author{
Ярослав Сиваківський \\ Львівський національний університет імені Івана Франка \\ вул. Ген. Чупринки, 49, 79044, Львів, Україна \\ e-mail: syvakivskiyyaroslav@gmail.com \\ https://orcid.org/0000-0002-1008-6229
}

В статті розглянуто питання професійного позиціонування журналіста в умовах активної збройної агресії проти його країни. Зокрема, проаналізовано основні стандарти роботи журналістів у мирний час, їхня відповідність до воєнних реалій.

Було вивчено попередні дослідження науковців стосовно проблеми, проведено аналіз їхніх висновків та співставлення з роботою українських журналістів з початку збройної агресії Росії.

Доведено, що ніякі професійні стандарти у час нападу країни-агресора не можуть бути важливішими за громадянську позицію.

Ключові слова: стандарти ВВС, стандарти журналістики, професійна етика, збройний конфлікт.

Анексія Криму та вторгнення Російської Федерації на території Донецької та Луганської областей поставило нас перед новою реальністю - життя в умовах війни. Українські громадяни зіштовхнулися з проблемами, до яких не були готові - швидка мобілізація населення, спрямування ресурсів на допомогу армії, намагання не стати жертвою інформаційних атак тощо.

I якщо суспільство доволі швидко пристосувалося до нових умов, то українська журналістика не була готова до таких змін. Репортери просто не зрозуміли, як діяти - залишатися «нейтральними професіоналами» чи бути насамперед громадянами своєї країни.

Виникли відверті дискусії, про які мало хто згадував раніше, як відкрито протистояти відвертій і свідомій брехні російської журналістики, як зробити ефективними українські інформаційні кампанії [1]. Постала етична проблема - чи може журналіст, до якого за замовчуванням прислухається велика кількість людей, використовувати свій вплив значно ширше професійного призначення. Проте разом з тим хіба не безпека Батьківщини та співгромадян $є$ найпершим завданням журналіста?

Упродовж останніх років доволі часто можна почути про «необхідність дотримуватися стандартів BВС»: балансу думок та точок зору, оперативності, достовір-

(с Сиваківський Я., 2019

Наукове рецензування та рекомендація до друку - проф. Кость С. А. 
ності, відокремлення фактів від коментарів, точності подачі інформації та повноти представлення фактів. Але чи можемо ми у час інформаційної війни, яка триватиме ще довгі роки, керуватися лише професійними стандартами іноземного видання? Хіба не варто коригувати усі стандарти під ті умови та виклики, які постали перед нами? Що має бути першим для жителя країни, на яку здійснили воєнний напад: професія чи громадянська позиція?

Усі ці запитання зумовлюють актуальність нашого дослідження. Дати на них об’єктивну відповідь важливо бодай тому, що агресія Росії на Сході нашої держави триватиме ще довго, позаяк передумов для ствердження зворотного наразі немає.

Журналісти - чи не найважливіші суб'єкти в інформаційній війні. Саме від них залежить, які терези переважать - нашої правди чи солодких обіцянок легкого шляху, який нав'язує нам ворог.

Аналіз досліджень. У роботі було проаналізовано праці С.А. Костя, Г.Г. Почепцова, М.О. Мацуки, О.В. Прудникової та інших авторів. У своїх дослідженнях науковці сходяться на думці, що при нападі агресора на країну журналіст перестає бути об’єктивним передавачем інформації та по суті стає бойовою одиницею інформаційного фронту, який є не менш важливий, аніж військовий.

Мета дослідження полягає у визначенні професійної позиції українського журналіста під час збройної та інформаційної агресії проти його країни. Як вирішити дилему: професійні стандарти чи інтереси держави? Втім, слід критично розглянути це питання -проблема насправді існує чи нав'язана кимось зі сторони?

Вивчення попереднього досвіду, аналіз впливу журналістів на суспільство під час агресивних інформаційних атак Російської Федерації, розгляд журналістських стандартів та вимог воєнного часу є завданням нашого дослідження.

Завданням дослідження $є$ вивчення попередніх праць науковців, присвячених цій проблематиці, проекція їхніх висновків на сьогоднішні реалії та дослідження етичного позиціонування журналістів в період збройної агресії проти України.

Незалежна журналістика та свобода слова - головні атрибути демократичного суспільства. Медіа диктують інформаційну повістку дня, контролюючи таким чином владні органи, намагаються зробити суспільство більш поінформованим про важливі події.

Етичні кодекси, спираються на «стандарти ВBC», адже це видання вважається прикладом неупередженості, об’єктивності та професіоналізму. Про які ж стандарти йде мова? Інститут масової інформації (IMI) називає 6 стандартів, яких повинен дотримуватися український журналіст згідно з Етичним кодексом [2]:

1. Баланс думок і точок зору. Відповідно до п. 10 Етичного кодексу українського журналіста, точки зору опонентів, в тому числі тих, хто став об'єктом журналістської критики, мають бути представлені збалансовано. Так само мають бути подані оцінки незалежних експертів.

2. Оперативність. Пункт 1 Кодексу професійної етики українського журналіста визначає, що головний обов’язок журналіста - сприяти забезпеченню права громадян на одержання оперативної інформації.

3. Достовірність (посилання на джерела). Пункт 6 Етичного кодексу українського журналіста визначає, найпершим обов'язком журналіста є повага до права громадськості на повну та об’єктивну інформацію про факти та події. Будь-яка тема потребує максимально повного набору фактів і думок. Тому завдання журналіста все 
це знайти в компетентних джерелах. Міжнародна декларація принципів поведінки журналістів закріплює, що журналіст зобов’язаний подавати інформацію, посилаючись на факти, походження яких він/вона знає.

4. Відокремлення фактів від коментарів. Пункт 9 Етичний кодекс українського журналіста встановлює, що факти, судження та припущення мають бути чітко відокремлені одне від одного.

5. Точність подачі інформації. Пункт 1 Кодексу професійної етики українського журналіста встановлює, що журналіст поширює і коментує лише ту інформацію, у правдивості якої переконаний. Він уникає неповноти або неточностей чи викривлень інформації, які могли б завдати моральної шкоди честі та гідності людини, неприпустимі з його боку недостовірні повідомлення.Міжнародна декларація принципів поведінки журналістів закріплює, що повага до істини та права громадськості на правду - перший обов'язок журналіста.

6. Повнота представлення фактів та інформаџї з проблеми. Згідно з п. 6 Етичного кодексу українського журналіста, найпершим обов'язком журналіста $є$ повага до права громадськості на повну та об'єктивну інформацію про факти та події. Будьяка тема потребує максимально повного набору фактів і думок. Тому завдання журналіста все це знайти в компетентних джерелах.

Але чи реально (припустимо?) дотримуватись цих стандартів у час активного збройного протистояння? Наприклад, екс-шеф-редактор «Нового каналу», а нині редактор «Телевізійної служби новин» Ігор Куляс вважає, що журналіст мусить це робити. На його думку, журналіст «має давати точку зору двох сторін, а не тільки проукраїнської» [3]. Чи можемо ми з ним погодитися? Навряд.

Позиція Ігоря Куляса - це стандарт «баланс думок та точок зору», що в мирний час є обов'язковою вимогою для подачі інформації. Але чи можна розглядати збройну та інформаційну агресію Росії проти України як звичайний конфлікт? Чи можемо ми надавати платформу для висловлювання тим, хто хоче нас захопити або знищити? Який Етичний кодекс виправдає таку діяльність? Дослідники етики журналістики стверджують, що «при висвітленні подій у зоні АТО головним для ЗМІ $є$ відображення позицій обох сторін конфлікту або максимальне прагнення до об’єктивності» [4], але яка в цьому потреба? Якою є мета трансляції позиції ворога у широкі маси? Демотивувати власне населення? Знівелювати усі спроби подолати ворожу пропаганду? Це суперечить будь-якій логіці. Можемо запитати: «На кого працюють стандарти у час війни?».

Також доволі цікавою виглядає необхідність наявності «незалежних експертів», проте як ми перевіримо їхню незалежність? Ні для кого не секрет, що в Україні майже немає незалежних та неупереджених ЗМІ. То перевірка яких критеріїв дозволить нам говорити про те, що експерт незалежний, а не працює на ворога або внутрішнього противника? Цікаво, що сам термін «незалежний експерт» передбачає «відповідальність за неправдивість наданих даних». Але у наших реаліях жоден «експерт», який прогнозував занепад України, інфляцію, відтік кадрів та поразку нашої армії, не поніс ані найменшої відповідальності за злочинну у час війни дезінформацію.

Наступний пункт - достовірність інформації. 3 цією вимогою не можливо не погодитися, але потрібно робити наголос на запитаннях «А як саме потрібно подавати цю інформацію?», «Які наслідки це матиме?». Воєнний час вимагає не лише точності інформації, аби запобігти впливу ворога на маси, але й прогнозувати вплив 
трансляції певної інформації у широкі маси. Теж саме стосується «повноти» подачі інформації - треба розуміти, що кількість жертв, позиції наших військових тощо апріорі не можуть подаватися.

Очевидно, що збройна агресія проти рідної країни впливає на весь устрій життя, і на професійні журналіста вимоги теж. Інформаційний порядок денний надзвичайно важлива річ у час збройного протистояння ворогу, проте українська журналістика програла цей плацдарм, і сприяли цьому «стандарти ВВС», які скомпрометували себе, ставши зручним інструментом для маніпуляцій, коли правда й відверта брехня помилково зрівнюються між собою, залишаючи вакуум невизначеності, коли журналіст хоче показати, що він «над битвою», осторонь процесів, що відбуваються [5].

При більш глибокому вивченні стає зрозумілою «нейтральна» позиція більшості журналістів. Усіма найвпливовішими українськими ЗМІ володіють олігархи, пов'язані з Росією, тому й аудиторію вони хочуть зробити або проросійською, або «нейтральною». Зокрема, за інформацією відповідних державних установ (Державної статистичної служби України, Книжкової палати ім. І. Федорова) та органів (Державний комітет телебачення і радіомовлення, Національна рада України 3 питань телебачення та радіомовлення) галузь масової інформації характеризується високим рівнем пов'язаності з політичними партіями та фінансово-промисловими групами [6: 105].

Але повернемося до стандартів. Доволі сумнівною у час війни виглядає вимога «повноти подачі інформації». Наприклад, втрати на лінії фронту - це прерогатива військових, тому журналісти можуть подавати лише ту інформацію, яку почули на брифінгу представника РНБО. Потрібно розуміти, що військові ідентифікують загиблих, повідомляють рідним та близьким цю жахливу звістку, і лише потім дають цю інформацію у суспільство. Неприпустимо, щоб здогадки журналістів посіяли паніку у суспільстві. Також не має права повідомляти про локацію розташування та напрям пересування українських військ. Хоча власне з цією вимогою журналісти погоджуються без обговорення, адже розуміють, що у разі витоку цієї інформації ворог завдасть удару, внаслідок якого можуть загинути люди. Втім потрібно, аби журналісти розуміли, що не лише це правило потрібно порушувати задля безпеки країни.

Те ж саме стосується оперативності подачі інформації. Якщо журналіст зняв сюжет на лінії фронту - він мусить дати його на перевірку військовим, аби упевнитися, що в кадр не потрапило нічого зайвого, а у його словах немає жодного натяку на локацію підрозділу, під охороною якого він перебуває.

Цивільні журналісти також повинні обачніше ставитися до того, що поширюють. Справа в тім, що зараз інформаційні портали працюють конвеєром: на сторінці сайту свіжа новина має з'являтися кожні 10 хвилин. Це неабияк грає на руку ворогу, адже журналіст просто не має часу перевірити інформацію - він публікує новину, вказуючи джерело, таким чином перекладаючи відповідальність за правдивість даних на нього.

Ми вже бачили прецеденти, коли ЗМІ мусили вибачатися за недостовірність інформації. Проте такі випадки поодинокі, а порушень етичного кодексу власне у перевірці даних набагато більше. Негативна риторика засобів масової інформації $є$ притаманною більшості суспільства. Цікаво, що є відсоток людей, які власне фінансове благополуччя ставлять понад безпеку та суверенітет держави. У цьому можна 
звинувачувати як Міністерство інформаційної політики, яке не зуміло створити чітку програму дій для протистояння з ворогом на інформаційному полі, так і журналістів, які у погоні за високими рейтингами та піаром власних персон забули про свою місію та завдання.

Висновки. Війна встановлює нові правила. Коли ззовні державу атакує ворог, потрібно робити усе, аби відбити його напад. Кожен, хто намагається відмежуватися від ситуації різноманітними професійними стандартами та етичними кодексами створює для ворога чисельну більшість, адже може й несвідомо, але допомагає йому.

Кожен журналіст повинен розуміти, що збереження територіальної цілісності держави - його першочерговий обов'язок, і саме ідею боротьби за соборність та незалежність, особливо в час війни, він має транслювати широкій аудиторії.

Мас-медіа визначають «інформаційний порядок денний» та розставляють акценти на інформаційному полі країни. І якщо війна перестане бути головною темою для журналістів - вона втрачатиме вагомість і для громадян, що створить ворогу сприятливий плацдарм для поширення дезінформації та демотивуючих гасел.

Коли журналіст вирушає у відрядження висвітлити збройний конфлікт інших країн - він може дозволити собі бути нейтральною стороною. Якщо агрессор напав на його країну - журналіст стає солдатом інформаційного фронту і насамперед має керуватися не професійними стандартами і етичними нормами, а ідеєю збереження незалежності своєї країни.

\section{REFERENCES}

1. Журналістика і війна: навч. посібник / С.А. Кость. Львів: ЛНУ ім. Івана Франка, 2016. $414 \mathrm{c}$

2. Журналістські стандарти : інформаційна довідка [Електронний ресурс] // Інститут масової інформації. 2011. 31 трав. - Режим доступу: https:/imi.org.ua/monitorings/ jurnalistski-standarti-informatsiyna-dovidka/

3. Стандарти й етика журналістики в умовах неоголошеної війни [Електронний реcypc] // MediaSapiens. 2014. 29 жовтня. - Режим доступу: https://ms.detector.media/ ethics/standards/standarti_y_etika_zhurnalistiki_v_umovakh_neogoloshenoi_viyni/

4. Портрет українського журналіста в умовах неоголошеної війни на Сході України / Є.В Бірюков // Матеріали Міжнародної науково-практичної конференції, Морально-етичний дискурс сучасних ЗМІ в координатах викликів доби: (Буча, квітень, 2016). К.: Міленіум, 2016. 160 с.

5. Журналістські стандарти та протидія інформаційним атакам Кремля: як поєднати [Електронний ресурс] // Радіо Свобода. 2018. 20 січня. - Режим доступу: https:// www.radiosvoboda.org/a/28985834.html

6. Державна інформаційна політика як механізм реалізації інформаційної функції сучасної держави / В. М. Вакулич, О. Є. Бухтатий // Публічне управління: теорія та практика. 2014. Вип. 1. С. 97-107. - Режим доступу: http://nbuv.gov.ua/UJRN/ Pubupr_2014_1_17 


\title{
JOURNALISTIC STANDARD SIN WARFARE: CITIZEN'S POSITION VERSUS OBJECTIVE PROFESSIONALISM
}

\author{
Yaroslav Syvakivskyi \\ Ivan Franko National University of Lviv \\ Gen. Chuprynky street, 49, 79044, Lviv, Ukraine \\ e-mail: syvakivskiyyaroslav@gmail.com \\ https://orcid.org/0000-0002-1008-6229
}

The issue of professional positioning of a journalist in the conditions of active armed aggression against his country is considered in this article. The following position of the previous scholass is studied: not only during the war, but also in peacetime, the journalist should first of all be a citizen of his country and act in favor of his state, and only then follow the standards of journalism.

Also, the study analyzed in detail such «BBC standards» as the balance of opinions and points of view, efficiency, reliability, separation of facts from comments, accuracy of information, completeness of presentation of facts. Since the purpose of the study was to determine the position of a journalist in a war against his country, we dwelt on explaining each standard, in particular as well as its interpretation according to the Ethics Code of a Ukrainian journalist.

In our work, examples are given when compliance with journalistic standards was at the expense of the Ukrainian Army and the state as a whole. Thus, the question arose: can the activity against the state in the time of armed attack on its territory from the Russian Federation justify the desire to adhere to professional journalism standards the answer is «no».

Since the journalist is an important unit of information warfare, which necessarily accompanies any armed attack, he must do everything to win his party. Clearly, no one will force him to manipulate or provide false information. However, his activities should be focused on the successes of his army and country, because otherwise he can demotivste the military and the population. That is why any standards in journalism should be adjusted according to the requirements of wartime.

A journalist should do everything to make his material, albeit small, but a positive achievement for his state, which opposes the aggressor. It is necessary to understand that the enemy spends very large resources on information attacks, and if it does not get a clear response - it will be extremely difficult to withstand this war.

Key words: BBC standards, journalistic standards, professional ethics, armed conflict. 